\title{
A Rational Design to Maximize Genome Editing Using Directed Nanostructures
}

\author{
Wesley Luzetti Fotoran* and Gerhard Wunderlich \\ Department of Parasitology, Institute for Biomedical Sciences, University of São Paulo, Brazil
}

Submission: February 22, 2018; Published: March 12, 2018

*Corresponding author: Wesley Luzetti Fotoran, Department of Parasitology, Institute for Biomedical Sciences, University of São Paulo, Brazil, Email: wesleylfw@hotmail.com

\section{Rational Design to Produce Maximum Effect on Bioengineering}

The recent advances in producing biomaterials and pointspecific genetic modifications enable novel and site-directed applications. Combining particular features of both techniques may result in new forms of treatment with an unprecedented impact. Here, we discuss how the combination of two techniques in one treatment can be applied to possibly initiate a new era of biomedical treatment.

\section{Targeting Specific Cells for a Selective Effect}

Selective treatment is a general goal in bioengineering. The capacity of precisely targeting specific cells results in fewer side effects as the principal advantage [1]. Ideally, a specifically directed particle is loaded with a cell-specific cargo which then reaches its target cell by docking to a specific receptor found only on the to-be-targeted cell population or tissue. There, it would elicit the desired effect [2]. This strategy may be applicable in many fields. For example in malaria infections, Plasmodium-infected red blood cells would be the target of drugs in contrast to non-infected red blood cells [3]. Immune cells such as dendritic cells can be a target by incrementing the reaction against vaccine antigens [4]. One of the most studied areas probably is to target specific cells in cancer. Central cells in cancer development such as cancer stem cells that continuously produce new carcinogenic cells [5] or even differentiated tumor cells may be targeted by directed nanoparticles [6]. For normal stem cells, there is a lack of applications in selective targeting. The most probable explanation for this is the delicate development of these cells and the potential long-lasting effect of treatments targeting these cells [7]. Therefore, a disruption in the normal development of these cells can easily turn these cells into cancer stem cells as a potential side effect [8]. Another challenge is to target the central nervous system where physiologic barriers, e.g. the blood-brain barrier, have to be overcome in order to create access of the cargo to this tissue [9-11].

\section{Target Specific Genes for Selective Genetic Repair}

Probably the most revolutionary form of bioengineering is the use of CRISPR/Cas9 to edit genomes with the possibility to introduce single nucleotide changes [12]. The use of Cas9 in genetic repair has almost chirurgical precision and different forms of genetic editing can be performed by Cas9. One of the most important applications is to use Cas 9 and a specific guide RNA to cut the target in the coding sequence and use a DNA donor sequence to produce a Homology-Directed DNA Repair [13]. This strategy emerges with a high degree of success to treat the genetic disorders in the CRYGC gene that causes cataracts [14] and the CFTR gene that causes cystic fibrosis [15]. The specificity of the system and the potential use of a donor sequence permits a unique capacity of genetic modification for the replacement of any genetic code for a designed sequence. A problem with this strategy remains in the fact that the effect is restricted to the cells that receive the treatment and do not spread to all tissues since it is not yet an approvable procedure for embryonic cell treatment. Another problem that emerges from the technique is that guide RNA, Cas9, and the donor sequence have to enter the target cell at the same time [16]. A possible solution is to use nanostructures to carry all the elements in one structure and then provide more efficiency to genome editing.

Combination of specifically designed nanoparticles and genetic modifications for long-lasting treatment

In specific cases, the targeting of resident stem cells in tissues with engineered nanoparticles still can provide long-lasting and definitive beneficial effects [17]. For example, cationic liposomes can be used to entrap plasmids encoding Cas9 and the guide RNA as well as the donor sequence inside an aqueous core. On the outside, antibodies can be used to guide these particles into specific cells, e.g. CD4 lymphocytes, as shown in Figure 1. These cells are an excellent target for CXCR5 deletion by homologous recombination, potentially protecting the CXCR5-deleted 
cells against HIV infection. The natural ability of these cells to expand in clonal populations permit that lymphocyte lines without CXCR5 receptor proliferate and become resistant to HIV infections with partial restoration of CD4 lymphocytes. Another possibility is the use of immuno-liposomes to target stem cells in bone marrow precursors of lymphocytes. In hypothesis, upon targeting of a subset of precursors cells, populations of cells resistant to HIV infection could be established. In our hands, Jurkat cells (a human CD4+ line) had easily their CXCR5 receptor replaced by a donor DNA sequence in vitro. This was achieved by treatment with immuno-liposomes specific for CD4 molecules and loaded with Cas9, guide RNA and donor encoding sequences for introducing double-strand DNA breaks, repair and subsequent knockout of the CXCR5 gene (Figure 2). Possibly, the same technique may be applied in whole organisms leading to the subsequent establishment of HIV resistant lymphocytes.

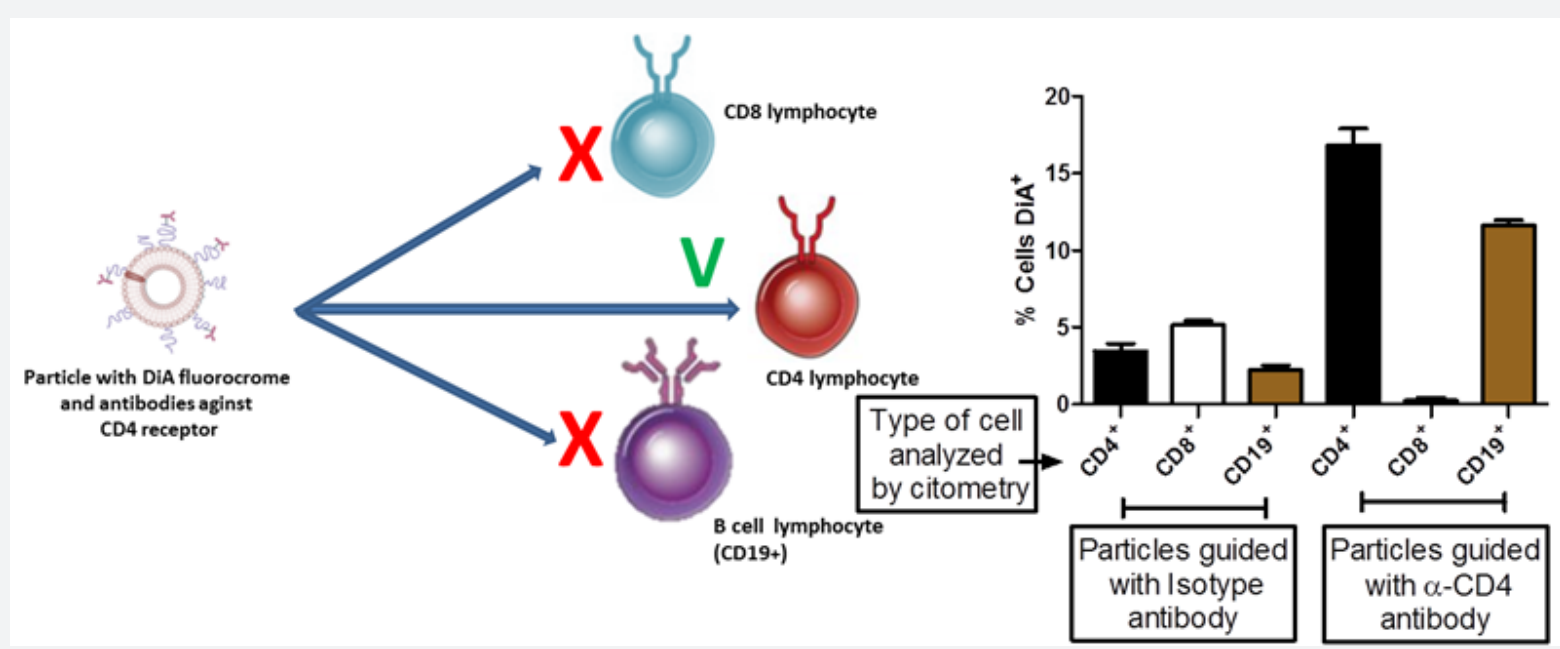

Figure 1: Binding of immunoliposomes against the CD4 receptor in vivo. Immunoliposomes guided against the CD4 receptor and containing the lipophilic fluorochrome DiA were injected in mice via the tail vein. As control, immunoliposomes with a Isotype control antibody were used. The splenocytes from treated mice was stained for CD8, CD4 and CD19 molecules and tested after 2 hours for the presence or absence of DiA fluorochrome by cytometry.

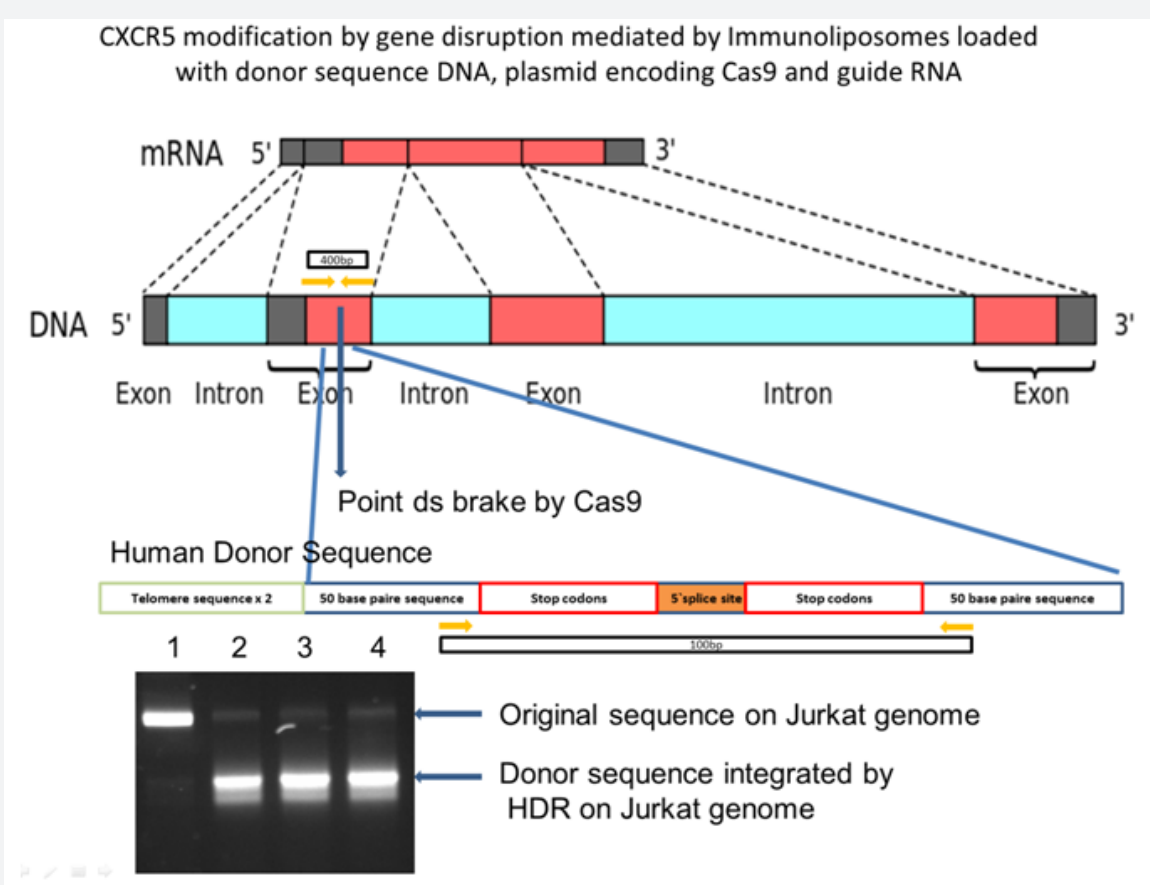

Figure 2: Genome editing in Jurkat cell genomes in the CXCR5 gene mediated by Cas9 and homologous direct recombination after immunoliposome fusion. Schematic representation of the original sequence of CXCR5 and the insertion by recombination with the donor sequence. The orange arrow indicated the position of the primers used for PCR amplification. The substrate genomic DNA was from unmodified cells (lane 1) and from Jurkat cells (lanes 2-4, three independent experiments) treated with liposomes containing plasmids encoding Cas9, modified donor sequence and sgRNA. HDR is homology directed recombination. 


\section{Future in Biomedical Engineering}

In conclusion, the range of possibilities using directed nanoparticles, on one hand, and cell-specific cargo (drugs or even genetic material such as plasmids), on the other hand, seem quite limitless. The research community should ideally create an awareness of the power of possibilities and include at a very early time point discussions about ethical aspects, specifically when dealing with upcoming therapies which are applicable also in germline modifications [18].

\section{Acknowledgement}

This work was founding by Fapesp, grant: 2015/17174-7 and 2016/19145-7.

\section{References}

1. Eloy JO, Petrilli R, Trevizan LNF, Chorilli M (2017) Immunoliposomes: A review on functionalization strategies and targets for drug delivery. Colloids Surfaces B Biointerfaces 159: 454-467.

2. Madni A, Sarfraz M, Rehman M, Ahmad M, Akhtar N (2014) Liposomal Drug Delivery: A Versatile Platform for Challenging Clinical Applications. J Pharm Pharm Sci 17: 401.

3. Moles E, Urbán P, Jiménez-Díaz MB, Viera-Morilla S, Angulo-Barturen I, et al. (2015) Immunoliposome-mediated drug delivery to Plasmodium -infected and non-infected red blood cells as a dual therapeutic/ prophylactic antimalarial strategy. J Control Release 210: 217-229.

4. Badiee A, Davies N, McDonald K, Radford K, Michiue H, et al. (2007) Enhanced delivery of immunoliposomes to human dendritic cells by targeting the multilectin receptor DEC-205. Vaccine 25: 4757-4766.

5. Song H, Su X, Yang K, Niu F, Li J, et al. (2015) CD20 Antibody-Conjugated Immunoliposomes for Targeted Chemotherapy of Melanoma Cancer Initiating Cells. J Biomed Nanotechnol 11: 1927-1946.

6. Riaz MK, Riaz MA, Zhang X, Lin C, Wong KH, et al. (2018) Surface
Functionalization and Targeting Strategies of Liposomes in Solid Tumor Therapy: A Review. Int J Mol Sci 19: 195.

7. Laird DJ, von Andrian UH, Wagers AJ (2008) Stem Cell Trafficking in Tissue Development, Growth, and Disease. Cell 132: 612-630.

8. Asare A, Levorse J, Fuchs E (2017) Coupling organelle inheritance with mitosis to balance growth and differentiation. Science 355: eaah4701.

9. Boado RJ, Pardridge WM, Boado RJ, Pardridge WM (2011) The Trojan Horse Liposome Technology for Nonviral Gene Transfer across the Blood-Brain Barrier. J Drug Deliv 2011: 1-12.

10. Pardridge WM (2007) Blood-brain barrier delivery of protein and nonviral gene therapeutics with molecular Trojan horses. J Control Release 122: $345-348$

11. Santiago-Tirado FH, Onken MD, Cooper JA, Klein RS, Doering TL (2016) Trojan Horse Transit Contributes to Blood-Brain Barrier Crossing of a Eukaryotic Pathogen., MBio 8: e02183-e02116.

12. Ding Y, Li H, Chen LL, Xie K (2016) Recent Advances in Genome Editing Using CRISPR/Cas9. Front Plant Sci 7: 703.

13. Aird EJ, Lovendahl KN, Martin ASt, Harris RS, Gordon WR (2017) Increasing Cas9-mediated homology-directed repair efficiency through covalent tethering of DNA repair template. bioRxiv 231035.

14. Wu Y, Liang D, Wang Y, Bai M, Tang W, et al. (2013) Correction of a Genetic Disease in Mouse via Use of CRISPR-Cas9. Cell Stem Cell 13: 659-662.

15. Schwank G, Koo BK, Sasselli V, Dekkers JF, Heo I, et al. (2013) Functional repair of CFTR by CRISPR/Cas9 in intestinal stem cell organoids of cystic fibrosis patients. Cell Stem Cell 13: 653-658.

16. Peng R, Lin G, Li J (2016) Potential pitfalls of CRISPR/Cas9-mediated genome editing. FEBS J 283: 1218-1231.

17. Ilas DC, Churchman SM, McGonagle D, Jones E (2017) Targeting subchondral bone mesenchymal stem cell activities for intrinsic joint repair in osteoarthritis. Futur Sci OA 3: FSO228.

18. RE (2018) Ethical Issues in Genome Editing using Crispr/Cas9 System. J Clin Res Bioeth 7: 1-4.

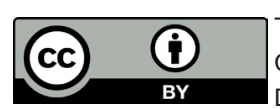

This work is licensed under Creative

Commons Attribution 4.0 License

DOI: 10.19080/CTBEB.2018.12.555843

\begin{tabular}{|l|}
\hline \multicolumn{1}{|c|}{ Your next submission with Juniper Publishers } \\
will reach you the below assets \\
- Quality Editorial service \\
- Swift Peer Review \\
- Reprints availability \\
- E-prints Service \\
- Manuscript Podcast for convenient understanding \\
- Global attainment for your research \\
- Manuscript accessibility in different formats \\
( Pdf, E-pub, Full Text, Audio) \\
- Unceasing customer service \\
Track the below URL for one-step submission \\
https://juniperpublishers.com/online-submission.php \\
\hline
\end{tabular}

